\title{
Application and Practice of the " Scaffolding + BOPPPS" Teaching Mode for Building Fire Engineering Based on Rain Class
}

\author{
Song Ying*, Li Haixia, Zhang Xiaoxiao, Zheng Ling, Wu Shuang \\ College of Management Science and Engineering, Shandong Technology and Business University \\ Yantai, Shandong, China
}

\begin{abstract}
Starting from the reality of higher education teaching, taking the construction of fire protection engineering " $3 \mathrm{H}$ " as the teaching goal, and the registered fire engineer's examination outline as guidance, this paper determines the key difficulties of the construction fire engineering project, builds the course unit support system, and integrates the lecture content. In the teaching design of the well-designed scaffolding and BOPPPS teaching mode, the teaching knowledge is effectively transmitted to the students through the design and application of teaching materials such as typical cases, and the use of the rain classroom platform. The whole teaching process is clear and smooth, which can convey new knowledge to students clearly and effectively and achieve good teaching effect.
\end{abstract}

Keywords-building fire engineering; scaffolding teaching mode; BOPPPS teaching mode; rain classroom

\section{INTRODUCTION}

With the rapid development of economy and the accelerating urban construction, various functional buildings have emerged in an endless stream. The data shows that there have been 31,000 high-rise building fires, 474 deaths and 1.56 billion direct property losses in the last decade. Therefore, a fire prevention and elimination project in the process of urban construction is particularly important, which also puts forward higher requirements for fire engineering personnel. Training high-quality fire engineering professionals has become one of the most important issues to ensure social safety and economic development.

As a compulsory professional course for safety engineering major, Building Fire Engineering is a comprehensive course to explore fire laws and study fire prevention and control theory and technology. According to the "Notice of the Higher Education Department of the Ministry of Education on the development of new engineering research and practice" [1]issued by the Ministry of Education. The new engineering is summarized as "five new": the new concept of engineering education, the new structure of disciplines, the new model of talent cultivation, the new quality of education and teaching, and the new system of classification development. Under this background, in accordance with the goal of training engineering technicians of safety engineering specialty to "develop morally, intellectually, physically and aesthetically in an all-round way, with broad foundation, strong ability and high quality", and on the basis of the existing teaching system, actively promote the curriculum construction and classroom teaching reform, and constantly explore and innovate the "Building Fire Engineering" course in the classroom teaching organization, teaching content design, teaching methods and means of personnel training mode.

\section{CONSTRUCTION GOAL FOR BUILDING FIRE ENGINEERING COURSE}

Focusing on the curriculum construction goal of "Teaching Knowledge, Capacity Building and Value Leading", we will build " $3 \mathrm{H}$ " teaching goals of "Head", "Hand" and "Heart". "Building Fire Engineering" aims to familiarize students with the system structure and working principle of building fire protection system through various teaching links, master the basic theories and methods of design analysis, installation and commissioning of building fire protection system, and form a certain fire protection design and management and other engineering practice ability, training firefighting and safety professional and technical personnel who can adapt to on-site technical work. At the same time, it lays a theoretical foundation for students to pass the examination of registered fire engineer smoothly after graduation.

\section{APPLICATION AND PRACTICE OF " SCAFFOLDING + BOPPPS" TEACHING MODE IN CONSTRUCTION FIRE ENGINEERING COURSE}

\section{A. Building a Curriculum Unit Knowledge System Based on the Registered Fire Engineer's Examination Syllabus}

The building fire engineering course is the main content of the "Fire Safety Technology Practice" in the National Registered Fire Engineer Professional Qualification Examination. Based on the examination syllabus of registered fire protection engineer. , the structure of the fire protection engineering course system is adjusted to form the basic theory ,basic principle, engineering applications and other related modules in the course of teaching, To delete old content, avoid or reduce duplication between courses. Some contents require students to study independently, highlight key and difficult points in the teaching process, strive to achieve "less, more refined, wider and new" and construct the curriculum unit support system. 


\section{B. Teaching Design of Building Fire Protection Engineering Based on Scaffolding Teaching Mode}

Through reviewing relevant literature, it is found that the research of "scaffolding teaching" is mostly concentrated in the fields of English, chemistry and physics in junior high school, and it is less used in the higher education stage[2,3], especially in safety science and engineering[4,5]. The literature in relevant professional courses in the subject area is rare. Therefore, the application of the scaffolding teaching in the professional teaching of colleges and universities has great exploration and practical significance.

The scaffolding model is derived from Vygotsky's "nearest development zone" theory [6], which mainly refers to the ability level and potential ability of students to solve problems independently or the ability to be achieved with the help of teachers and peers. In other words, the so-called "most neighboring development zone" theory means that in the process of learning, teachers help students to eliminate the differences between problems and abilities that need to be solved through teaching. With this idea, the "scaffolding" used in the construction industry is introduced into the learning process as a visual metaphor. By constructing appropriate "scaffolding", the "nearest development zone" of student intelligence is established, and the intellectual level of students is continuously improved. Carrying out higher levels of cognitive activities truly maks teaching ahead of development. According to this architectural metaphor, "scaffolding" gradually develops into an effective support in learning process, and becomes a "scaffolding teaching method", which provides a conceptual framework for learners to construct their understanding of knowledge. The core of the scaffolding teaching design of building fire engineering course is that the creation of the situation must be conducive to the meaning construction of the learners' learning content, so as to determine the learning scope of the unit module, and bring the students into a meaningful problem situation to guide in-depth analysis, discussion and solution of a series of problems. Take the "Basic Knowledge of Fire" unit as an example, as shown in Table I.

TABLE I. SCAFFOLDING TEACHING DESIGN OF BUILDING FIRE ENGINEERING COURSE MODULE

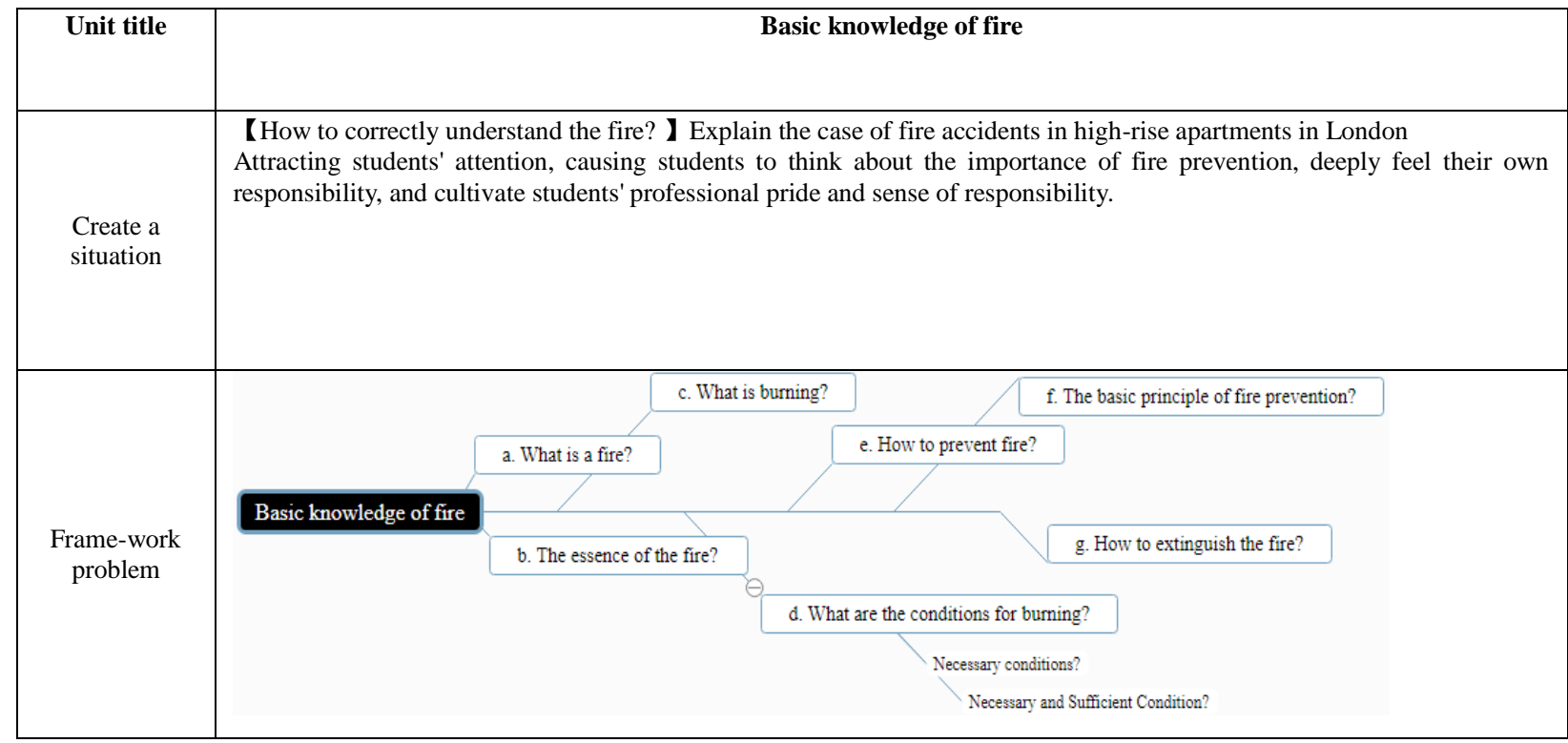

\section{Teaching Design of Building Fire Engineering Based on BOPPPS Teaching Mode}

BOPPPS teaching mode is the theoretical basis of the Canadian Instruction Skills Workshop (ISW) system, which is an advanced teaching mode with emphasis on students. The model consists of the following six teaching sessions: bridgein, objective/outcome, pre-assessment, participatory, postassessment, and summary [7].

Through this mode, the teaching process of a class is decomposed into six sub-modules that are connected before and after, and the teaching objectives of the course are achieved through sub-modules. At the same time, through effective interaction (teaching appointments, brainstorming, problem-oriented learning, fish tank teaching, etc.), students' enthusiasm for learning is fully adjusted, students' participation is enhanced, teacher-student interaction is enhanced, in participatory learning. And the change of teaching form is adapt to the diversified teaching objectives, and their own to re-examine teaching, constantly improve teaching skills, enhance their confidence in teaching, and ultimately achieve the effect of promoting students' learning. The teaching design of BOPPPS based on the "Basic Knowledge of Fire" unit is shown in Table II.

\section{Teaching Design of Building Fire Engineering with the Scaffolding and BOPPPS Teaching Mode}

The teaching design of the building fire engineering with the scaffolding and BOPPPS teaching mode is shown in Fig.1. 


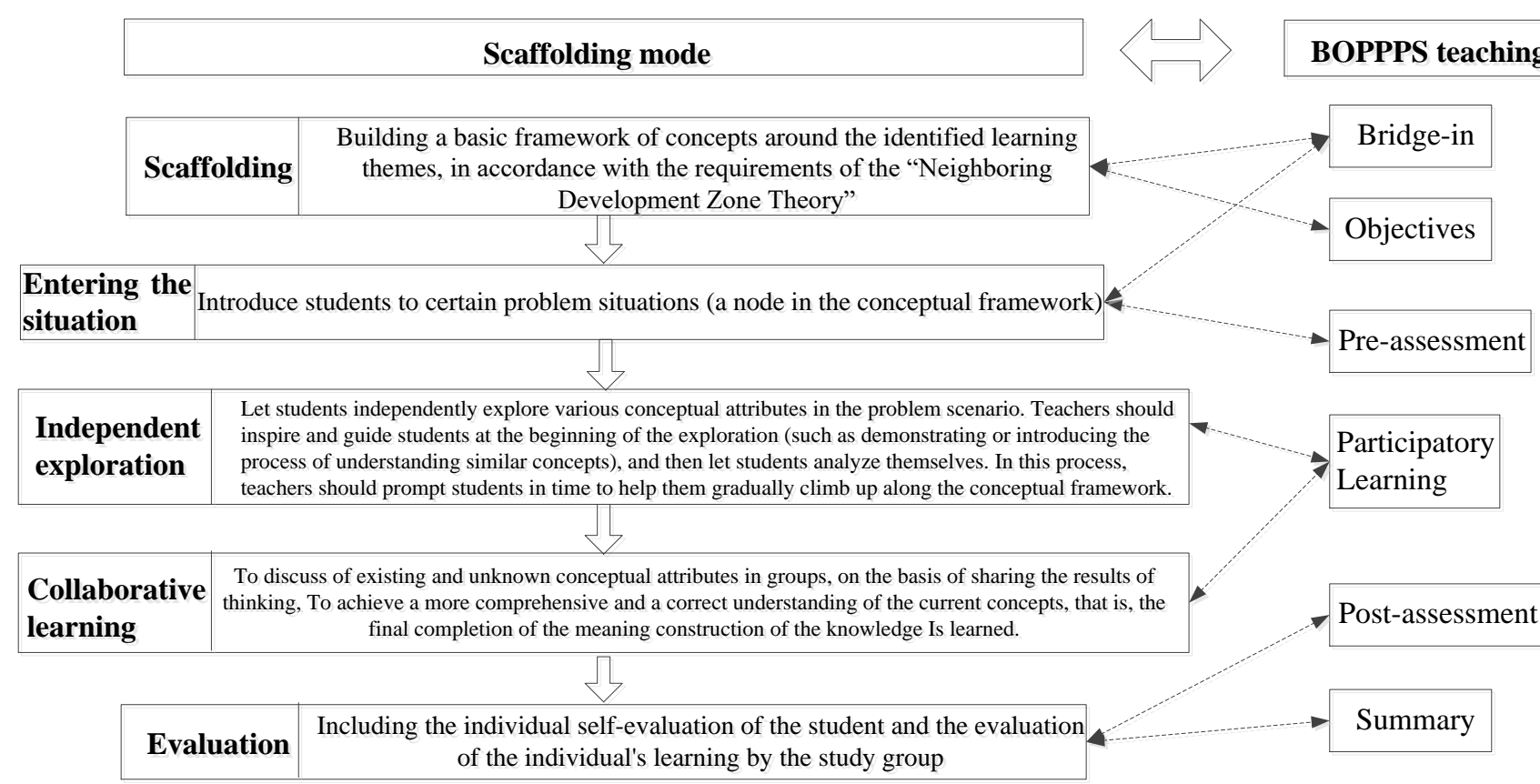

Fig. 1 Teaching design of building fire engineering with the scaffolding and BOPPPS teaching mode

IV. CLASSROOM TEACHING OF BUILDING FIRE PROTECTION ENGINEERING BASED ON RAIN CLASSROOM DURING THE WHOLE PROCESS

The Rain Class is a smart teaching tool launched by Tsinghua University, which is mainly used as teaching tools in higher education. Rain Class is a plug-in built into PowerPoint (PPT) that install the rain class and open the PPT to see the rain class. Rain classroom is mainly composed of three parts: mobile phone, desktop and remote server. Students only need a smart phone equipped with Wechat to achieve interactive classroom teaching between teachers and students. The features of the rain class include: barrage interaction, PPT synchronization to the student's mobile phone, classroom problem push (including multiple choice questions, multiple choice questions, subjective questions and voting, etc.), students "do not understand" feedback, pre-class preparation and after-school homework push, etc. [8]. 
TABLE II. BOPPPS TEACHING DESIGN

\begin{tabular}{|c|c|c|}
\hline BOPPPS & Teacher activities & Student activities \\
\hline Bridge-in & $\begin{array}{l}\text { 【How to correctly understand the fire? 】 } \\
\text { Explain the case of fire accidents in high-rise apartments in London. }\end{array}$ & Thinking about the importance of fire prevention \\
\hline Objectives & $\begin{array}{l}\text { 【Communicate teaching objectives 】 } \\
\text { Through study, students can: } \\
\text { 【Cognition】 } \\
\text { 1.Use fire and combustion mechanisms to distinguish between fire and } \\
\text { combustion; } \\
\text { 2. Analyze necessary conditions and necessary and sufficient conditions } \\
\text { for combustion; } \\
\text { 3. Master the basic theory of fire prevention and fire fighting methods. } \\
\text { 【Skill】 } \\
\text { Through classroom interaction, students' ability to apply theoretical } \\
\text { knowledge to solve practical problems is enhanced. } \\
\text { 【Affection】 } \\
\text { Through case explanations and lectures, students are encouraged to think } \\
\text { about the importance of fire safety work, thereby stimulating interest in } \\
\text { learning and enhancing students' professional pride and sense of } \\
\text { responsibility. }\end{array}$ & Thinking and listening \\
\hline Pre-assessment & $\begin{array}{l}\text { 【Submit questions】 } \\
\text { What are the three elements of burning? }\end{array}$ & Thinking and answering questions \\
\hline $\begin{array}{l}\text { Participato-ry } \\
\text { Learning }\end{array}$ & $\begin{array}{l}\text { Interspersed examples, questioning interactions in the process of } \\
\text { teaching, causing students to think: } \\
\text { 1. What is the nature of the fire? } \\
\text { 2. Oxidation reaction must occur in the event of combustion. Is the } \\
\text { oxidation reaction necessarily burning? (eg:Fe) } \\
\text { 3. The essence of burning: } \\
\text { 4. At the same time, it has the necessary conditions for combustion, but } \\
\text { there is no burning phenomenon. Why? (eg: quantity and concentration } \\
\text { requirements of combustibles, concentration of combustion aids, } \\
\text { minimum ignition energy of the ignition source, interaction between the } \\
\text { above basic combustion conditions) } \\
\text { 5. How to prevent fire? } \\
\text { 6. Fire extinguishing method (eg: oil pan fire, etc.) }\end{array}$ & $\begin{array}{l}\text { Participating in interaction and answering } \\
\text { questions }\end{array}$ \\
\hline Post-assessment & $\begin{array}{l}\text { 【Links to True Topics】 } \\
\text { 1. When the ignition tetrahedron is used to represent the necessary } \\
\text { conditions for the occurrence and development of combustion, the term } \\
\text { "tetrahedron" refers to combustibles, oxidants, ignition sources and (D). } \\
\text { A. Oxidation reaction } \\
\text { B. Thermal decomposition reaction } \\
\text { C. Chain Transfer } \\
\text { D. Chain Reaction Free Radicals }\end{array}$ & Answering questions \\
\hline Summary & $\begin{array}{l}\text { 【Review of course points】 } \\
\text { 【Next section knowledge notice】 } \\
\text { 1. Classification of fires; } \\
\text { 2. The hazard of fire; } \\
\text { 3. Common causes of fires. }\end{array}$ & Discussing and summarizing the learning gains \\
\hline
\end{tabular}

\section{CONCLUSION}

In the concept of teaching, we deeply understand the "book-based" education concept, pay attention to the use of advanced teaching concepts and teaching information technology, and explore the effective path of "knowledge transfer, ability training and value leadership."

In the teaching process, the "student-centered" curriculum system is constructed, and the " $3 \mathrm{H}$ " teaching is taught. In the teaching design, the teaching objectives that Head, Hand and Heart are established in the whole teaching system on top of the design.

In the teaching method, the scaffolding teaching mode and the BOPPPS teaching mode are merged, the knowledge is taught according to teaching purpose, the teaching design is analyzed through the teaching + discussion + instance, the typical accident case is incorporated, the students are encouraged to discuss and think, and the students are trained to solve the practical problems.

In terms of teaching methods, multimedia teaching is used to make full use of modern wisdom teaching tools--rain classroom. Rain classroom integrates complex information technology into PowerPoint and $\mathrm{WeChat}$, and establishes a bridge between extracurricular preparation and classroom teaching, so that classroom interaction can never be straight.

In the course of knowledge teaching, the "multi-track operation" mode of "real topic + case" practice, ideological education and theoretical teaching are conducive to strengthening the cultivation concept of "knowledge + skills + value guidance", improving students' ability of integrating theory with practice, applying knowledge comprehensively, and making this ability sustainable development and ultimately promoting, so that students can flexibly use the "learned" and "study" links. 
Through the second semester of the 18-19 school year, the practice of two classes of safety level 16 shows that using this model can improve students' classroom enthusiasm, enhance classroom atmosphere, and timely get feedback from the students' learning status and knowledge points through data, which can effectively improve students' learning efficiency.

\section{REFLECTIONS ON TEACHING}

Although certain achievements have been made in the course construction, it is necessary to further strengthen and improve in the following aspects, and adopt various optimization measures to deepen the effect of classroom teaching in order to achieve greater results.

In the future education and teaching work, the following needs to be done:

(1) More effective forms of interaction should be adopted, such as teaching appointment, games, snowball method, fish tank teaching method, etc., to embody the "student-centered" educational concept, so more students can participate in the course learning, and further improve the classroom participation of students;

(2) To establish a more effective incentive mechanism for curriculum assessment, we should fully mobilize the enthusiasm of students for learning and better exercise their oral expression ability and team cooperation ability through a variety of marking mechanisms such as random roll-call, group discussion and personal presentation in rainy classrooms.

(3) It is necessary to teach more ideas to solve practical problems, more processes and case studies, guide students to self-learning and self-digesting theoretical knowledge, guide students to climb upwards and gradually realize "flip classroom".

\section{REFERENCES}

[1] Department of Higher Education, Ministry of Education. Notice of the Department of Higher Education of the Ministry of Education on the development of new engineering research and practice [2017] No. 6 [A/OL]. 2017-02-20,http: / /www.moe.edu.cn / s78 / A08 / A08 _ gggs / A08_sjhj/201702 / t20170223 _297158. Html.

[2] CHEN Peng, "Research on Scaffolding Instruction on Fire Protection Engineering Teaching," Higher Education Forum, Issue 1, pp. 90-92, Feb.2008.

[3] Peng CHEN,Yeming LIU, "Teaching design research of fire protection engineering based on constructivism", Scientific Research, Education of Creative Professionals of Safety Engineering Facing 21st Century.

[4] SONG Ying, LI Tianran, YANG Keyue,et al. "Teaching design an practice research of scaffolding fire engineering course under the guidance of professionalization". Education Science (Full Text), 2019, 1(1): 230-231.

[5] SONG Ying, LI Haixia ,SHI Junwei, et al. "Research on the Scaffolding Teaching Design and Practice of Building fire engineering Course with Professional Direction". International Conference on Management, Education Technology and Economics (ICMETE2019), Volume82:167170

[6] Vygotsky, "Vygotsky's educational theory selection". Beijing: People's Education Press, 2005

[7] SUN Yanan, WANG Nan, ZHANG Dongmin, et al. "Study on the Effective Teaching of Young Teachers in Colleges and UniversitiesBased on the Analysis and Application of BOPPPS Mode". Education Modernization,2017,4(45):134-136.

[8] The school launched the wisdom teaching tool online - Rain Class Tsinghua University, 2016-06-28, http://news.tsinghua.edu.cn/publish/thunews/9660/2016/2016061710175 8935397134/20160617101758935397134_html. 